Article

\title{
Rationality and Ethics between Western and Islamic Tradition
}

\author{
Michele Mangini ${ }^{10}$ \\ Department of Law, University of Bari, 70121 Bari, Italy; michele.mangini@uniba.it
}

Received: 4 July 2018; Accepted: 6 October 2018; Published: 7 October 2018

\begin{abstract}
In the contemporary legal and political debate a large space is taken by the concept of 'reasonableness' as a multifaceted notion. Its plasticity makes it very adaptable to the variety of problems that is called on to solve. Its philosophical underpinnings are located in the tradition of Western thought. On the one hand, we have the modern tradition, including the Kantian and the Humean views and, on the other, the Aristotelian-Thomistic tradition, proposing a different and competing conception of reasonableness. Insofar as the latter tradition proposes an idea relying on perfectionist considerations, I want to inquire into the Islamic tradition of reason and rationality in order to find whether it is closer to the first or to the second model. Concepts such as 'ijitihad', 'maqasid' and 'maslaha', I shall argue, find their better explanation if interpreted along the Aristotelian perfectionist tradition rather than along its competitor. If this move is well-founded, some important consequences for the understanding of contemporary Islamic culture may derive. My basic assumption is that those Islamic concepts (and a few others) embed a religious and cultural core of tension to 'human development' that can nicely dovetail with Aristotelian rationality and ethics of virtues.
\end{abstract}

Keywords: Islamic ethics; Western ethics; reasonableness

\section{Premise}

In the contemporary age there is one political (and cultural) rivalry that is underlying the rise and fall of many political parties and government policies in Western (European) countries. It is the political rivalry between Western and Islamic countries that emerges through wars, massive migrations and, finally, terrorist attacks. Increasingly Muslims come to be perceived by European populations as "the Other", someone who is extraneous to European culture and values. In my view Europeans have only two main options that are open in front of them: On the one hand, the political option can be described as "erecting walls" and defending European values and identity against "the Other" as someone who cannot be integrated. This view is increasingly taking the upper hand in many countries in Western and Eastern Europe. On the other hand, there is what I would call the "cultural option", worth-exploring because less conflictual, though also less persuasive at the level of media communication. It would consist in digging underneath the surface of differences and oppositions in order to retrieve elements of commonality and eventual overlapping of values and principles. Attempts in this direction may be launched at the political level, for example by arguing in favor of the inclusion of Islamic values within the liberal framework of Rawls's public reason. ${ }^{1}$

These attempts are surely worth-pursuing but would probably leave many Muslims unpersuaded by the inclusion of their values and the place theorists assign to religion among those values within

1 Cf., for example, Fadel (2007); March (2009). 
a secular and pluralistic framework such as Rawls's public reason. The "cultural option" requires to go one or two steps deeper and address some basic concepts that pervade Western and Islamic culture. $^{2}$ I believe the best possible candidate for this exploration is the concept of "reason" which is at the center of Western philosophy since the classical age and represents also the inspiration of at least 'half' of classical Islamic philosophy (Mutazilite)—where the other half is inspired by "religion" over reason (Asharite). I believe that reason in its declinations of rationality and reasonableness is a crucial focal point toward ethical values. I may anticipate that our inquiry will bring back encouraging parallels between Western and Islamic reason and ethics but also some degree of dissimilarity. This may sound like a meager result but it seems worth pursuing to move some steps beyond the present harsh opposition. In turn, I want to emphasize the extent and the direction to which reason connects to ethics. We shall not dwell on theoretical reason but on practical reason as an area in which the virtues show how we can find more overlapping than is usually expected between Western and Islamic ethics. I shall contend that the virtues explicate a certain understanding of reason that can be best described as "reasonableness". Its main features, on the one hand, mark its difference from other contemporary understandings of reason such as the Kantian and the Humean views. On the other hand, however, those features mark the similarity of reasonableness-through the exercise of the virtues-with a certain understanding of Islamic reason. It is important to emphasize right at the start that the understanding of reasonableness that will emerge from the discussion is not in contrast with Rawls's well-known idea of 'public reason' which is aimed at including within political liberalism all comprehensive views that respect "constitutional essentials". Rather what will emerge is a view more ethically than politically based in which reasonableness is connected to some extent to the development of human nature in a way that cuts across some crucial Western and Islamic views. It is possible to hold, in my view, that the conception that emerges does not take an alternative stand with regard to Rawls's but may be taken as an integrative conception that, on the one hand, does not violate the basic liberal requirements of pluralism of values and respect for individual rights, while, on the other, may get some degree closer to Islamic sensibilities by relying on a conception of reason and human values that belongs to their tradition as well as to the Western one.

In short, the agenda in front of us includes, first, an overview of the Kantian and Humean approach to reason as setting the main models of contemporary modernity. In my view, these models remain to some degree foreign to the Islamic understanding of reason. My second stage will consist of a sketchy inquiry in which we need to give careful consideration to an alternative Western conception of reason. This conception can be considered as the long-standing Western tradition which goes back to classical Greece and through the Latin period and the Middle Ages transmits its core ideas to our times. It is not a univocal understanding but I will focus on its most well-known and influential version: the Aristotelian-Thomistic conception of reason and the virtues. This inquiry opens the way to a third stage showing the main lines of some Islamic approaches to reason and ethics. It will emerge how concepts such as "human welfare and development, virtues and happiness" play a crucial role in a relevant part of Islamic ethics, such Al-Ghazali's and Ibn Taymiyya's ethical theories. I shall conclude by emphasizing how a promising terrain of consent between Western and Islamic ethics can be found in the-partial-overlapping between the Aristotelian-Thomistic conception of reason and the virtues and a large part of Islamic ethics, namely what has been called "Soft Natural Law".

\section{Kantian and Humean Conceptions of Reason}

In this section I propose myself an ambitious though not impossible task that we cannot skip in order to proceed with the further stages of the argumentation. At this stage we need to show the

2 I keep on using two semantically different attributes, opposing a geographical locator and a religion for a well-known reason. Although elements of Christianity are still strongly present in our culture, this is pervaded as well of secular elements belonging to classical thought, the Enlightenment and Romanticism just to name the most well-known. Thus, the "Western" culture represents a complex whole that stands on its own. 
main features of the Kantian and Humean approaches to rationality. An overview of the mainstream contemporary approaches to morality in contemporary Western philosophy confirms the dominant position of substantive moral concepts deriving from Kant and Hume, such as duty and utility. Thus, notwithstanding their profound differences with regard to rationality and morality, it seems plausible to hold that their views have contributed to shape the contemporary Western moral landscape to such an extent that any attempt to argue for a different view has to start from and come to terms with them.

I shall start with a presentation of the main points in Kant's view of practical rationality and its relation with morality and move at a second stage to introduce the basic features of Hume's view. Given the extension and variety of the debate generated by both philosophers in the debate about the main issues of practical reason (setting aside all reflections about theoretical reason), my comments on both Kant and Hume will necessarily appear skeletical. However, I do hope to be able to preserve a focus of ideas that at one time shows their contribution to the contemporary relationship between rationality and morality, and marks a distinctive point with regard to the classical Aristotelian-Thomistic conception that will be discussed later.

Insofar as Hume leaves only a marginal role for reason in practical matters it seems fair to start from Kant's account of practical reason - which to some extent remains also closer to the traditional account than Hume's. Kant's chief interest in the Groundwork for the Metaphysics of Morals is that of deriving a supreme principle of morality from the practical faculty of reason and its "universal rules of determination". ${ }^{3}$ Starting from morality as 'duty' or moral necessitation, Kant considers practical reason primarily as a faculty of self-constraint: in his view, then, reasons do not harmonize with empirical desires-as it happens in the classical view—but guide our conduct even against desires. He is concerned both with substantive reasons for action and with those general principles that underlie the different reasons-now often called "requirements of rationality".

The gist of Kant's account of practical rationality can be summarized—as already noticed—in a conception of self-constraint, as carried forward by principles of rational self-government. "Empirical desires become relevant to practical reason only when they engage its principles by being taken up in maxims and the pursuit of ends through purposive choices". ${ }^{4}$ What is distinctive in Kant's view of the relationship between practical reason and desires is his distrust for the latter and the role that he assigns to the former in critically evaluating all desires on the grounds of a set of principles proceeding from the faculty of reason itself. Thus, it is only reason that motivates to action or, at least, desires as scrutinized and evaluated by reason.

The motivation takes place through the imperatives that constrain our choice in deliberation. Famously, Kant distinguishes categorical and hypothetical imperatives. In both cases the imperative applies to an action set to reach an end. However, in the case of the hypothetical imperative the end is given to reason independently of the rational imperative, while in the other case it is the categorical imperative itself to set the end. ${ }^{5}$ For our purposes of confrontation of views of rationality with regard to morality it is only fair to emphasize that Kant considers two general kinds of ends as rationally required by categorical imperatives: our own perfection and the happiness of others. ${ }^{6}$ At this level the connection between rationality and morality is stricter and most relevant to the purpose of our confrontation with the classical view.

In order to make justice to the articulate, though not very clear, views that Kant holds with regard to practical reason I should also briefly dwell on instrumental reason and practical reason. It is important to keep in mind that in both cases we have hypothetical imperatives at work. This may seem less clear in the case of instrumental reason which covers those "imperatives of skill" that belong to all arts and sciences and are based on merely empirical connections of cause and effect. However, they are

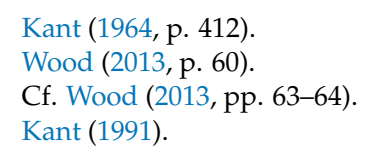


not commands of reason that strictly necessitate certain actions because many rules may bring about a certain end. By contrast, Allen Wood stresses that rules of skill are hypothetical imperatives that rest on a 'general' hypothetical imperative: "whoever wills the end also wills (insofar as reason has decisive influence on his actions) the means that are necessary to it that are in his control". ${ }^{7}$ Differently from Hume, here the role of reason is not simply the theoretical one to know the means to a certain end but the practical one to constrain myself to perform a certain action. It is by the same rational act of setting myself an end that I normatively subject myself to the practical norm of willing the means to that end.

Now we come to Kant's account of prudential reason which is important to Kant only with regard to his main topic: Moral reason. In understanding what he says with regard to prudential reason it is necessary to clarify his views about happiness: this is not just an empirical end but can be presupposed a priori as an actual end for every finite rational being. ${ }^{8}$ This claim is not incompatible with the contrary claim that each individual's idea of happiness is never determinate and coherent. Thus, there are no imperatives of prudence, only rules that result in happiness for most people. Differently from the classical tradition Kant does not want to claim that there is an objective conception of happiness of which we can identify some well-determined, though flexible, features. Rather he seems to align with Hume and the utilitarian tradition when he interprets happiness as "the greatest achievable satisfaction" of each individual's inclinations. ${ }^{9}$ As we shall see, when we come to contents, this view of happiness remains foreign to the ethical objectivism of the classical view.

In order to find room for the construction of a scale of priorities in the realization of one's happiness in Kant's conception it makes sense to follow Allen Wood's interpretation. Wood takes the end of happiness to have a unique priority from the standpoint of prudential reason when we take it normatively: What reason requires is "happiness understood not as momentary contentment but the sum total of empirical satisfaction with 'our whole existence'" ${ }^{10}$ If I have a momentary desire for a hot chocolate and know the means to satisfy it but I am also aware of my intolerance to milk and derivatives, I should not let a momentary impulse override the long-term end of my happiness as a whole. Observing the requirements of prudential reason, Wood comments, does not concern means-ends relations but "the priority between the rational end of happiness and all the other contingent ends that are based on inclinations or empirical desires" ${ }^{11}$ Thus, it is at least doubtful that the imperative of prudential reason can be paralleled with those of instrumental reason as hypothetical imperatives, as Kant does. Rather, Wood suggests that in parallel with our moral duty to make the happiness of others an end for us, we should take prudence as a rational regard for our humanity and, thus, give priority to our happiness over other ends of inclination. However, this is never spelled out clearly by Kant. ${ }^{12}$

Some final considerations are in place with regard to the virtues. Given the account of Kant's practical reason just provided, it is no surprise that his account of the foundations of virtues does not rely on general consent, the common point of view-as we shall see with Hume-but on something rather different. The virtuous person, according to Kant's understanding, cannot simply be one that is approved by general consent but someone who acts for "right reasons", i.e., reasons that are valid objectively, for all human beings.

Now, some commentators, such as Wood, align Aristotle's 'right reason'—which expresses itself in the plurality of virtues-with Kant's motive of 'morality' or 'duty'. Through this motive the will leads to choose "only that which reason, independently of inclination, recognizes as practically necessary,

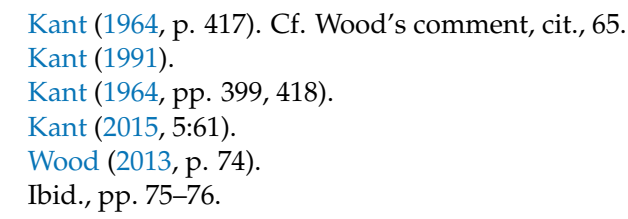


i.e., as good. ${ }^{13}$ It is here, I would emphasize, that Kant parts ways with Aristotle who believed in a harmonious agreement between desires and reason. A virtuous action for the former but not for the latter may imply the agent's struggle against some of his inclinations.

Famously, the Enlightenment presents us with another influential view against which even Kant had to struggle. Hume's philosophy merges at several points with utilitarianism but, in order to offer a general overview of Hume's conception of rationality, we do not need to get involved with utilitarianism here. With regard to our purposes in this paper I believe a fair account of Hume's views can focus on: (1) His general skepticism concerning the power of reason; (2) the influencing motives of the will; (3) his account of the virtues.

(1) Once the Kantian autonomy of reason is rejected the Humeans propose the alternative thesis according to which reason can only be instrumental to aims generated outside it. These aims rest in desires or preferences that individuals have taken at their face value. Reason is unable to operate any filter beyond selecting the most efficient means to realize desires of preferences. Consequentialist analysis—usually taken as a part of utilitarianism—prescribes to maximize the (good) consequences of acts or rules and these are shaped according to our desires or preferences, whatever they are. Desireor preference-satisfaction-or pleasure in Benthamite utilitarianism—comes in as the theory of value according to which we can evaluate acts or rules. It is a unique measure of value which makes all different objects and activities commensurable. From this point of view we can rationally compare on the same scale of value things as diverse as a love affair and a well-paid job in a far-away town. There is no obstacle to utilitarian reasoning between commensurable goods that are compared only on the grounds of the quantity of utility they produce. Reason, on the utilitarian account, is unable to make any qualitative distinction among different ends. Also, ends of human conduct escape entirely the boundaries of reason, leaving the choice entirely in the hands of desires or preferences.

The instrumental rationality of utilitarianism has shown itself as one of the most powerful features of the contemporary understanding of reason but by far not the only derivation of the Humean thinking. Another important strand of his thought can be described as "sentimentalism" because, marginalizing reason to an instrumental role, it places all the strength that moves human beings to action on passions or feelings. Reason cannot operate as a filter on passions to the point that "tis not contrary to reason to prefer the destruction of the whole world to the scratching of my finger". On this view moral approval and disapproval, as much as virtue and vice, depend only on feeling a satisfaction or dissatisfaction of a certain kind from the observation of a character and his conduct. ${ }^{14}$

Hume's starting point is a general skepticism concerning the power of reason to penetrate the structures of reality. As the ancient skeptics, Hume admitted that we must live and that we have to follow nature-rather than reason-including natural appetites and instincts, in order to determine how to live. Reason can give its contribution, according to this view, by perceiving, remembering, calculating and inferring, but only within the boundaries of 'common life'. Mathematics and the experimental sciences are extensions of natural thinking and we have to keep them within the common life.

Beliefs are formed through what Hume calls "causal reasoning", that is a move from the impression or idea of a cause to the idea of its effect (and vice versa). He claims that these causal influences are not determined by reason. There is no argument that connects our premises and conclusions. ${ }^{15}$ I take Hume's position as a general skeptical position about the power of reason in induction. He may be taken to reject only a rationalist conception of practical reason, as Kieran Setiya holds ${ }^{16}$ or propose a thoroughgoing skepticism about practical reason. On this second view a common interpretation is that of Hume as an instrumentalist who is skeptic about rational deliberation of ends.

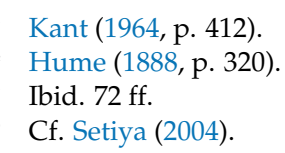


The famous passage which reads "tis not contrary to reason to prefer the destruction of the world to the scratching of my finger"17 seems to drive out reason from designing our ends. Thus, this view, strengthened by other passages such as "reason is, and ought only to be the slave of passions" 18 seems to lead to the instrumentalist thesis as dominant in Humean interpretation. ${ }^{19}$ Whatever the truth of the exegetical debate on Hume's position I would align here with the instrumentalist view which at one time is in line with the dominant interpretation of Hume on motivations and the will and makes its way through economic and utilitarian doctrines, as I shall try to clarify shortly.

(2) Against a long and outstanding tradition Hume denied that reason have the power to oppose the passions in motivating us to act. The direct passions are caused by ideas of pleasure and pain that derive from impressions that strike our senses. These are passions that motivate us to act but only when they derive from ideas of pleasure and pain that we believe exist or will exist. ${ }^{20}$ Thus, the will moves us to act as an immediate effect of pain or pleasure and, as it is well-known, reason alone can never be a motive to any action of the will. Thus, should we conclude that reason play no role at all in the generation of action?

Hume seems to grant that reason provides information about means to our ends, thus making a difference to the direction of the will. Reason alone cannot motivate us to action but it does have an instrumental role in the shaping of actions. The role of reason is auxiliary in offering probable or cause-effect reasoning that helps to decide what to do. However, what moves us to action is nothing else than our prospects of pain or pleasure that arise aversion or propensity to certain objects. ${ }^{21}$ When these prospects produce a passion this comes to control the will and only a contrary impulse can resist a passion, not reason alone.

A further argument which is worth-considering to sharpen our understanding of the role of reason in Hume's theory is "the representation argument" according to which our ideas are only representations or copies of external entities, while passions and volitions are "original facts and realities". 22 Being not mental representations, copies of original objects, passions cannot be contradictory to truth and reason, thus, actions, as generated by passions, cannot be reasonable or unreasonable. By contrast, Hume allows that a passion may be unreasonable because it arises in response to a mistaken judgment or opinion. Strictly speaking, in Hume's discourse it is the judgment to be unreasonable and not the passions. Once the mistaken judgment is corrected, "our passions will yield to reason without any opposition". ${ }^{23}$

So far it is fair to say that Hume leaves only a minimal task to reason in shaping the direction of one's life and actions. Reason has no word in devising the ends of action. These are left to passions or, as they will be rephrased in the utilitarian and economic tradition, to 'desires' or 'preferences'. Desire- or preference-satisfaction becomes the only ethical goal of individual life from this point of view. There is nothing that rationality can add in terms of practical deliberation about ends, no critical standpoint that allows the agent to discriminate between better and worse goods, superior and inferior styles of life. ${ }^{24}$ In my view Hume's undermining of the power of reason in the XVIII century is among the main underpinnings of the divorce between the ethical life (the search of the good life for man) and the moral life (the search for criteria to balance one's life and actions with those of others). The demise of reason in ethics leaves desires and preferences as the only psychological sources to identify what is worth-pursuing in life. At the individual level there is no counter-force to balance the motivating strength of desires/preferences. At the social level the unrestrained rise of economic

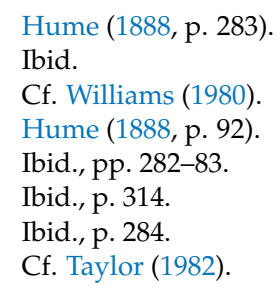


forces in contemporary Western societies can be explained also by the absence of an attractive goal for people, alternative to the maximization of preference- (desire-) satisfaction.

(3) A final set of considerations are in place with regard to morality in general and the virtues in particular. Hume's theory, as introduced so far, cuts him off from the ancient tradition in which the weight of reason through the exercise of the virtues gave a straightforward answer to the question 'why be moral?'. So, following his general theory, Hume's account to the virtues (and vices) is based on moral sentiments. More precisely virtues and vices are those traits the disinterested contemplation of which produces approval or disapproval, counting the first as pleasure and the second as pain or uneasiness.

As it is well known, "sympathy" is the key for understanding Hume's theory of virtues. Sympathy is the capacity by means of which we "receive by communication" one another's affections, sentiments, interests and opinions. ${ }^{25}$ Our appraisal of someone's character and virtues is guided by our capacity to sympathize with the effects of an agent's character.

However, what if our sentiments fail to sympathize simply because other characters are distant from ours or because someone's interests oppose our own? Hume responds to this kind of worries employing the metaphor of a point of view that is "steady and general" and from which we can achieve a 'stable' appraisal of character. ${ }^{26}$ Moral approval, then, seems to imply judgment to some extent and in this guise moral sentiment seems to involve reason or something analogous to reason. ${ }^{27}$ Hume himself reminds us that reason can oppose passion-and correct it—when by 'reason' we mean "a general and calm determination of the passions founded on some distant view or reflection", ${ }^{28}$ such as that of a general point of view. The general point of view or the "common point of view", as Hume also calls it, seems to play the role of reason in establishing a "standard of virtue to which our sentiments must conform if they are to count as moral appraisals with which others can be expected to agree". ${ }^{29}$

While Kant's structure of rationalistic justification placed a great weight on the principle of universalization, as we already know, Hume locates the spring of moral judgment in something as subjective as passions. Passions only concern the sentiments within us, what other people feel is irrelevant unless it affects our feelings. The role of reason on this view may at best be preparatory but never influence moral judgment.

A provisional conclusion on the position of reason in the Kantian and Humean accounts of morality cannot help emphasizing how they have both been profoundly influential on Western philosophy, though putting forward contrasting theses about reason. Whereas Kant takes reason up toward the height of universalism and detachment from human nature in order to offer undeniable justification in the public domain, Hume's understanding of reason leaves it with an instrumental role, ancillary to those feelings and passions we happen to have in the society in which we live. From a political point of view, Kant gives reason a critical standing over existing morality and justice, while Hume's position is necessarily subservient to existing morality. Both disconnect reason from human nature or-if we want to skip this controversial concept—at least from a minimal psychological makeup that balances the functioning of reason with desires, emotions and the will. As noticed at the start, for the purposes of this paper we should emphasize that both views neglect the relationship between reason and ethics in the sense of 'how to live one's life'. So what is 'reasonable' in the practical domain cannot encompass anything beyond moral principles or moral sentiments.

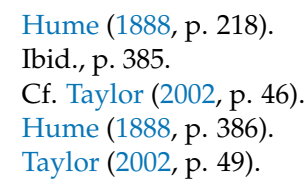




\section{The Classical Tradition of Western Philosophy}

Kant and Hume express two powerful positions which deeply influence modern morality, though in opposite directions. This can be properly understood only if one considers that each of them represents an unbalanced approach to human nature. In Kant's view the moral choice relies only on the rationalistic principle of the categorical imperative, marginalizing emotions and desires to which no moral value is attributed. By contrast, the instrumental role of reason in Hume's view leaves feelings and desires as dominating items of human psychology. What seems lost in modern moral theories is one of the crucial legacies of ancient philosophy, an understanding of human nature in which reason, desires and emotions are in balance. It is quite well-known that this difference is of the greatest consequence in ethical terms. Modern moral theories are either centered on deontological constraints that protect individual freedom (rights) or teleologically aimed at promoting the increase of overall welfare (utilitarian maximization). In either case these theories are offered as moral theories and decline any task of presenting ethical guidelines for individual conduct along the lines of classical ancient ethics. For example, according to the famous question addressed to Socrates at the beginning of Plato's Republic, the task of the (practical) philosopher is that of offering answers to the question "how should I live?". By contrast, modern moral theories do not have any objective grounding for a theory of the good: only subjectively can we know what is good for each of us. As a result of the influence of Kantian and Humean philosophy we are missing in our contemporary age the objectivist ethics that characterizes the ethical tradition of Aristotle and Thomas Aquinas. They have in common an important core of ideas and, especially with regard to the understanding of human nature, they can be considered as an alternative to modern moralities, notwithstanding their being respectively a secular and a Christian view. I want to hold that the Aristotelian-Thomistic understanding of human nature and ethics may offer a more friendly terrain of agreement with the Islamic thinking.

Even more than in the case of Kant and Hume I cannot help accounting for a complex structure of thought such as Aquinas' with a sketchy description that focuses only on some crucial points which, in turn, will constitute our 'vague' ground of comparison with Islamic philosophy. In a nutshell, we may plausibly pinpoint the Thomistic account of practical reason along the following concepts: human flourishing, desires and reason, prudence and the virtues, will and reason.

Given our focus on the concept of reason, it may seem misleading to start our sketchy reconstruction of Aquinas' conception of practical reason from human flourishing. It is not so once we reflect on its centrality in Aristotelian-Thomistic philosophy and its inextricable connection with reason. The ultimate goods of Aristotelian eudaimonia and Thomistic beatitudo are partly different because of the religious elements in the latter but they share at least: (1) An idea of prudential well-being as satisfaction of natural desires, connected to a description of human nature; (2) a moral idea of happiness, constituted by the virtues as regulative of the pursuit of fundamental goods; (3) the conjunction of prudential well-being and happiness that makes up human flourishing or perfection (that is proper to a rational creature); (4) in the case of Aquinas' the view that 'perfect happiness' can be achieved only through the further element of 'grace'.

In my sketchy reconstruction the concept of human flourishing in Thomistic philosophy is given by those natural inclinations which lead us to pursue (a) those goods that we have in common with all other living beings (such as life, health); (b) those we have in common with other animals (such as sustenance, security, reproduction and so on); (c) finally, those goods that are peculiar to human beings (such as rational activity, pursuing the truth, living in society and worshipping God). The pursuit of these goods structures a prudential conception of well-being, not dissimilar from Amartya Sen's and Martha Nussbaum's Aristotelian conception of 'human functioning and capabilities'. ${ }^{30}$ Insofar as this approach shows an Aristotelian gist directed at human development Aquinas shares it: it is well-known how the views of 'the Philosopher' —as Aquinas addressed Aristotle throughout his work—shaped 
to a large degree Thomistic philosophy. However, the prudential conception of well-being that emerges from these hints only acquires sense and significance in the light of Aquinas' ultimate good of "beatitudo". This is the perfect good that includes nothing bad and satisfies all desires (bonum perfectum et sufficiens). ${ }^{31}$ What is worth emphasizing is that this good expresses perfection, the greatest possible development of human capabilities, but within a moral framework: it is no more disconnected from morality, as it is the case of 'well-being' which is not a moral concept.

Given the weight of reason in human flourishing, according to the Aristotelian-Thomistic view, it is no surprise that the virtues combine natural inclinations toward human goods and rational ordering: they express "the reasoned integration and expression of basic human impulses". ${ }^{32}$ I will come back to the issue of the virtues in a short while. For the moment I want to notice how they are constitutive parts of the ideal of beatitudo or felicitas in its imperfect form. This is connatural to human beings with their capacities and imperfections and corresponds to Aristotle's notion of eudaimonia, taken in its practical sense. However, the perfect beatitudo, the highest achievement possible for human beings can only be 'God', attained through the exercise of our rational capacities in contemplation. Aristotle's second sense of eudaimonia seems in line with this conception of beatitudo but for the fact that the latter utterly transcends human natural capacities and depends on the divine element of 'grace'.

What has been conveyed so far takes us already to a good stage in understanding the relation between desires and reason in Aquinas' ethics. Desires are neither dominant over reason, as it happens in Hume, nor marginalized as dangerous psychological elements that contrast the functioning of reason, as it happens in Kant. Rather, according to Aquinas, there are some important desires, connected with natural inclinations which are disciplined and perfected through moral virtues. The exercise of the latter, as we shall see, is directed by reason in its most operative countenance. In order to understand the role of desires in Aquinas' picture of human psychology we should consider that, differently from contemporary theories, he takes most relevant desires to derive from the fundamental inclinations, already introduced, that we naturally have as human beings. Relevant desires are those that human beings have for intelligible goods that we pursue because necessary for our flourishing. These pursuits take place within a rational ordering in which the role of reason is balanced with the pull of desires and emotions, on the one hand, and the will, on the other.

My third and obvious move at this point is that of introducing the virtues in the picture of Aquinas' ethics. This is a large domain within his ethics and here I can only touch on some relevant points. The operation of the virtues is strictly connected to that of desires and, at one time, to reason. The ends of the virtues are set by principles of practical reason that, in turn, operate through the engagement with desires. Desires activate the virtues which are applied to action. ${ }^{33}$ Each virtue operates in a certain sphere of human conduct with its distinct desires. It is a separation that accounts for the perfection of the agent in different faculties. In turn, the virtues are also dispositions that incline the agent to feel and respond in certain ways.

The virtues represent normative ideals that guide conduct in areas of human conduct in which it is normal to choose and decide for a human being. The virtue of temperance, for example, concerns the almost universal experience human beings have with the pleasures of food, drink and sex. 'Temperance' can be interpreted as a trait of character whose operations contribute in important ways to human wellbeing, as much as it benefits the community to which the agent belongs (she is going to desire and pursue only moderate amounts of those pleasures, reducing conflicts with other agents).

However, in order to grasp the proper working of the virtues we need to consider carefully 'prudence' as the intellectual virtue through which practical reason becomes operative. Prudence is concerned with contingent singulars and is required to determine the mean of the moral virtues, such as temperance, in concrete situations. It identifies conformity with reason with respect to a

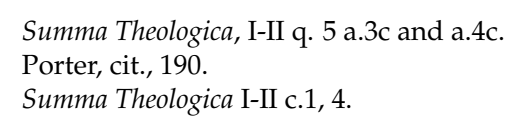


certain area of life, such as, for example, that of the pleasures of food, drink and sex. Prudence, in general, "is the virtue which enables an individual to discern and to choose in particular situations in accordance with her best ideals of a happy life". ${ }^{34}$ The prudent person applies judgment to concrete moral problems rather than employing a decision procedure based on rules. Its application requires previous knowledge of the salient particulars of the situation. This step also enters in the judgment of the situation. In turn, not only prudence determines e.g., what the temperate person would do in a certain situation but may also connect temperance with eventual other virtues whose exercise might be necessary in a certain situation. Aquinas follows Aristotle on the thesis of the unity of the virtues so that prudence or practical wisdom is the operative focus for the exercise of all the virtues. In addition it brings order to the diverse aims and considerations that enter into practical deliberation.

Finally, I should introduce the last but crucial element in determining deliberation in Aquinas' picture: the 'will'. The conceptualization of the will marks one of the most relevant points of distinction between Aquinas' and Aristotle's picture of human deliberation. According to a certain interpretation, "the will is a kind of desire, or in his terms, a kind of appetite. The will is the form of appetite proper to a rational creature" ${ }^{35}$ The will here is paralleled to the passions as forms of appetite, each oriented toward some perceived good. However, I believe that this interpretation does not take into sufficient consideration the relation between the will and the judgments of reason. ${ }^{36}$ By contrast, John Finnis seems correctly to bring the will closer to reason and defines it as "one's capacity to shape oneself by responding to reasons". ${ }^{37}$ Beyond the understanding of basic ends and the envisaging of a possible purpose to action that comes from reason, the will provides basic openness to these ends and an interest in pursuing the chosen purpose. The will gives its assent to the choice of specified purposes and, finally, to a certain determinate option that appears suitable for the agent (consensus). Another fundamental point in the functioning of the will is electio: The formation of a definitive intention and the adoption of a certain option among others. ${ }^{38}$

The will, according to this reconstruction, seems to introduce a further stage of deliberation that remained foreign to Aristotle's psychological picture. It is the closing between general reasons leading to the ultimate good of happiness and the personal biography of the agent with his dispositions and beliefs. The will focuses on interiority, on the location of the self with regard to the general good. In my view the most plausible account of the place of the will within human psychology according to Aquinas should consider it as embedded in a net of relations in which (the main) desires are intelligible structures that orient toward human goods. Reason presents to the will these possible objects of pursuit among which the choice may depend also on contingent circumstances and on the personal history of the agent. In a nutshell the assent that comes from the will responds to reasons that are never abstractly considered but are shaped according to the agent's particularity.

\section{Starting to Bridge the Gap with Islamic Ethics}

I have tried to show in an over-condensed manner the gist of Thomistic ethics as focused on the idea of reason and its different interconnections. In parallel I want to attempt a similar work of retrieval with Islamic ethics, focusing on two well-known figures who are not commonly taken as the main defenders of reason: Al-Ghazali and Ibn Taymiyya. My assumption is that finding a parallel between some of the main ethical concepts in these authors, on the one hand, and Aquinas, on the other, we can greatly strengthen the claim of a common ground between Western and Islamic ethics. In the attempt of drawing these one-to-one parallels we should pay attention to the general philosophical import of

\footnotetext{
Porter, cit., 319.

Ibid., p. 254

S.T. I-II 8.1.

Finnis (1998, p. 70)

Ibid., p. 71.
} 
an important part of Islamic ethics that has been named "Soft Natural Law" (SNL) in opposition to "Hard Natural Law" (HNL). ${ }^{39}$

Setting his field of enquiry within Islamic legal systems, Anver Emon centers on the question of the "ontological authority" of reason in Shari'a, in other words the place of reason as an authoritative source of Shari'a norms to be used when "revealed scripture or other authoritative source texts are silent" ${ }^{40}$ Before going some steps forward in considering the relation between reason and Shari'a we should consider an important and parallel point in Aquinas. His multi-layered construction gives a clear sense of the relations between nature and reason: the Lex Aeterna (Eternal Law) is God's law as understood in His mind. We can comprehend it through the Divine Law and Natural Law. The first is the law contained in scripture or revelation, while the second is what we can understand through the use of reason. The general idea is that human reason can connect to the divine mind through the medium of the created world, through those 'natural intelligibilities' that we have already identified as the objects of our main desires.

A large part of Islamic ethical thinking seems to be on the same line with the Aquinas: many authors insist on the "fusion of fact and value" in order to invest nature with both objectivity and normative value. However, while "Hard Natural Law" authors held that God only does good and that human beings can detect His benefits from nature, by contrast "Soft Natural Law" authors opposed the former decision by stating that God's benefits are not a consequence of His eternal goodness. ${ }^{41}$ "God does so purely out of His grace, which is subject to change if God so desires". ${ }^{2}$ Fusion of fact and value, then, is subject to God's discretion. This entails that our possibilities as human beings to determine what is good or bad, obligatory or prohibited, only depend on God's determinations and reason has no or little authority to resolve such matters. What happens, however, in situations in which there is no source text available, no clearly stated divine law? While Hard Natural Law authors were inclined toward a presumption of permissibility, Soft Natural Law voluntarists relied on a state of suspended judgment or, even, "a presumption of continuity" according to which "where no scripture governs a case, no liability is imposed for acting as one wishes". 43

SNL did not deny the fusion of fact and value held by HNL theorists but, first, with regard to law, reduced the human power to reason about the good and the bad but always subject to God's grace. Second, the introduction of theories of practical reasoning based on concepts such as maslaha or perceived good and maqasid al-shari'a or the basic purposes of the law (life, lineage, property, reason and religion) determines a number of arguments that can justify a rule of law in the absence of a source text. So, although the authority of reason is recognized, its scope of operations is also limited in the law because it can be used only in relation to maslaha and maqasid al-shari'a.

In general terms, if we want to keep our parallel between these positions and Aquinas' ethics we should observe that, on the one hand, in his view 'fundamental inclinations' in human beings determine to a large extent the direction and scope of practical reasoning. On the other hand, the thrust

39 Emon (2010).

40 Ibid., p. 3.

41 The distinction between Hard Natural Law and Soft Natural Law theories remains close to the classical one between Mutazilite and Ash'arite theories. The Mutazilite agreed on the fact that "the nature of right and wrong can be determined rationally and that it is ultimately independent of the divine prescriptions as laid down in the Koran" (Fakhry 1991, p. 31). In short the moral categories of right and wrong, they asserted, "can be known by unaided reason and the ground of their validity can be rationally justified". Ibid. Theologians such as Abd al-Jabbar, believed that principles established by reason do not need confirmation and validation by revelation. Principles and acts possess their goodness or badness intrinsically, it did not depend on God's will. By contrast, Abu'l-Hasan al-Ashari and his school-among the scholars Al-Juwayni, teacher of Al-Ghazali, is outstanding - took the opposite position with regard to goodness and badness: They are not essential qualities of the action but are what is commanded or proscribed by the religious law. On the same line Al-Sharastani emphasizes that no obligation is incumbent on God, neither those deriving from good and better or grace. It all depends on His unconstrained benevolence. (Cf. Fakhry (1991, pp. 47-50)).

42 Ibid., p. 32.

43 Ibid., p. 31. 
of reason in the Aquinas' beatitudo is limited once we consider its 'perfect' version in which the role of God's grace and will is crucial.

\section{Al-Ghazali's Understanding of Reason and the Virtues}

The first figure we are going to consider takes an outstanding position in the SNL camp and, further, is considered from another point of view as a synthesis among philosophical, religious and mystical currents in Islam. ${ }^{44} \mathrm{Al}-\mathrm{Ghazali}$ (who died about one century before Aquinas' birth) wrote extensively mostly in theology and ethics, dedicating his first work to a careful review of previous contributions of philosophers, theologians and mystics in their search for the truth and for God. While inclining toward the position of the latter, he puts forward in various works-but especially in the Mizan - an ethics characterized by a certain role for reason in dialogue with revelation and by the central position of happiness in the hereafter. In turn, concepts such as 'action' and 'virtues' are conducive to the realization of happiness. Finally, we should pay attention to his employment of maslaha in practical reasoning in order to check the necessary connection between what is factually good and what is to be done normatively.

In the first place at the epistemological level, notwithstanding Al-Ghazali's alleged mystical inclinations, the role of reason is crucial in developing his theological arguments. Far from imposing dogmatic truths he struggles against his philosophical and theological opponents on their own grounds. He wants to 'demonstrate' the validity of his interpretations rather than just asserting the truth. For obvious reasons of space we cannot follow Al-Ghazali's method of reasoning in the wide variety of his works but we can focus on two important points that show his accord with the Aristotelian-Thomistic line of reasoning.

First, he faces the problem of interpretations that deviate from the literal sense. When and to what extent can the authority of the literal text of revelation be set aside? In other words, when the human capacity of reason can overcome the literal meaning? His 'rule of interpretation' is that a deviation from "the literal meaning depends on the production of a demonstration that the literal meaning is impossible" ${ }^{45}$ If a demonstration proves the impossibility of the 'outward' meaning, the interpret has to achieve other levels of being where the words are attributed to a sensible perception of the Prophet or, even, to his imagination, the final level of interpretation is that of taking the words as a symbol or a metaphor. $^{46}$

Second, the strength of reason in Al-Ghazali's epistemology can be better grasped by following how his rule of interpretation divides the Qur'an and the prophetic hadith into three groups. "In the first group fall those passages that are contradicted by a demonstrative argument". ${ }^{47}$ Here reason, rather than overruling revelation, simply determines the meaning of the text in accordance with revelation. The outer (literal) meaning is overcome in favour of the inner meaning discovered by reason. In the second group "the results of demonstrative proofs either agree or do not affect the text of revelation". ${ }^{48}$ Finally, in the third group we find passages in which demonstrative proofs cannot contradict the information conveyed in revelation, as with the assertion of the afterlife in paradise or hell.

It should be emphasized that the concept of 'demonstration' employed by Al-Ghazali strictly follows Aristotle's teaching of logic, as he clearly shows in his Touchstone of Reasoning in Logic. Thus, we may conclude on the point by emphasizing how on the one hand, reason has an important function in understanding revelation because it may entrust us to prophetic revelation. On the other hand,

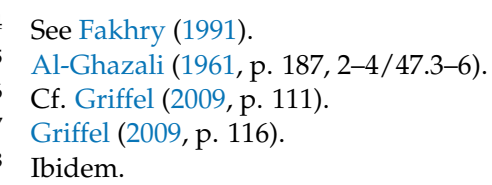


Al-Ghazali recognizes that even truths coming from heretic philosophers should not be rejected as such. (We shall see in a short while how reason plays an important role also with regard to maslaha.)

In the second place we should dwell to some extent on the ethical level to verify the importance of reason in Al-Ghazali's work. Following general reconstructions, such as Fakhry's, Al-Ghazali's main ethical works-Mizan al-Amal and Ihya Ulum al-Din-center on the same concept that also belongs to the Greek tradition on which many Islamic philosophers and theologians largely drew: happiness. Central in the pursuit of happiness is the idea of the 'soul' as what brings human beings close to God. Everything in the body has the function of assisting the soul, including all those senses and powers which we can find also in the lower animals-e.g., desires. The power which is peculiar to the human soul is reason, the power of knowledge. Knowledge is the first goal in Al-Ghazali's ethics. It should be directed, first, to realities of this world and the next that are imperceptible to the senses. This is the domain of theoretical knowledge. Second, we have the domain of practical knowledge that is directed to the consequences of action. ${ }^{49}$ Through action in this world we can pursue otherworldly happiness, a condition of perfection and pleasure that endures forever. In parallel with Aristotelian-Thomistic ethics Al-Ghazali takes action as necessary to harness the passions of the soul, controlling anger and other 'propensities' "so as to ensure that they will submit to reason". ${ }^{50}$ Directed by reason as the lordly (rabbaniyya) element of the soul, actions when performed deliberately and repeated for some time may have effect on the soul. Thus, the soul itself can acquire perfection by means of bodily acts.

Stressing the importance of repeating acts in order to achieve effects on the soul, Al-Ghazali is locating his ethics on the Aristotelian path that is later joined also by Aquinas. Aquinas develops his account of habits in his "Treatise on Habits" in the Prima Secundae of the Summa Theologica. Habits are of the utmost importance in Aquinas's ethics because we become virtuous through habits. He introduces, differently from Aristotle, the further concept of the 'will'-as we already know-that works interdependently with reason in shaping each habit. This is defined as "a disposition whereby that which is disposed is disposed well or ill, and this, either, in regard to itself or in regard to another: thus, health is a habit". 51

In the third place, the parallel drawn on habituation leads us straightforwardly to the doctrine of the virtues that Al-Ghazali develops following to a great extent Aristotle's main lines, as it will happen with the Aquinas one century later. Again, knowledge and action are the two main elements in the functioning of the soul which we should keep in mind to understand Al-Ghazali's doctrine of virtues. He locates the virtues within the context of the good character which is taken as an established state of the soul from which good actions proceed. Good actions, he says, are those that are praised by reason and the Shari'a. ${ }^{52}$ This is no place for an extended discussion of the virtues in Al-Ghazali. Rather, I should limit my considerations to notice that he focuses on the four main virtues of the classical tradition-wisdom, courage, temperance and justice-that correspond to four main faculties in the soul: from the faculty of knowledge the virtue of wisdom is generated in the soul; from the faculty of anger courage; from the faculty of desire we can derive temperance; and, finally, the virtue of justice arises from the faculty with the same name. Justice has the task of controlling the faculties of anger and desire according to reason and the Shari'a. While the role designed for justice by Al Ghazali seems a deviation with regard to tradition, the other elements and their relations remain very close to the Aristotelian tradition.

From the point of view of our attempted parallel with Thomistic ethics I should notice that in a good character wisdom is considered as the highest of all the virtues, as it is confirmed by the Quranic verse: "whoever is granted wisdom he indeed is given a great good". ${ }^{33}$ However, Al-Ghazali does

\footnotetext{
Cf. Quasem (1975, p. 47)

Al-Ghazali (1963, p. 12).

Aquinas (1888-1906). S.T. I-II, 49, 1.

See Al-Ghazali (1898, III, p. 46).

Qu'ran 2:269; Ihya III, pp. 47-48.
} 
not give wisdom only a speculative or religious sense-knowledge of God-but also very practical subdivisions such as: sagacity, sound judgment, perspicuity and right opinion. ${ }^{54}$ This sub-distinction within practical wisdom seems very close also to the classical tradition of Aristotelian phronesis and Thomistic prudence. The former is well-known to include judgment to discriminate about the things wisdom deals with, sense and sympathy, deliberative excellence, cleverness, understanding of particulars. ${ }^{55}$ Aquinas' account follows on very similar lines. Thus, we may conclude that there is a common ground among Aquinas, Al-Ghazali and Aristotle with regard to wisdom and the classical virtues. Further, much more could be said in strengthening the parallel between Al-Ghazali and Aquinas, if we consider the otherworldly dimension of their ethics. Differently from Aristotle, these two theologians do not consider one's sense of greatness or pride as a positive aspect of character but rather as a vice. Pride takes place when one considers his own worth better than that of others and he has contempt for others. There are different forms of pride, Al-Ghazali holds, being that against God the worst and that against people the least serious, though with evil consequences. ${ }^{56} \mathrm{He}$ counts on both knowledge and action to get rid of pride, showing the importance of reason in reaching awareness of one's place in the world and with regard to God. Action is also necessary to remove pride by deeds such as prayer that lead to effects opposite to pride. The rejection of pride acquires special importance especially in view of the central place of humility among the virtues Al-Ghazali names. ${ }^{57}$ Its understanding is very close to dignity for Al-Ghazali, as the mean between pride and servility. It is taken as a sense of one's own worth which also entails accepting others' worth-but not necessarily on the same footing with one's own. ${ }^{58}$

Although properly speaking humility belongs to the moral virtues, we should ponder on the way in which-together with the other moral virtues-it affects the thrust of practical reason. This takes a different shape in different philosophical and theological frameworks—such as, just to name a few well-known authors, Plato, Aristotle, Al-Ghazali, Thomas Aquinas, Ibn Sina, Ibn Taymiyya-in which there is mutual influence between (practical) reason and the virtues. The secular versus religious framework of thought that distinguishes some of these thinkers plays important differences in their doctrines. So, notwithstanding the well-known line of continuity between Aristotle and Aquinas, there are differences in their understandings of practical reason that are strictly dependent on their conceptions of the virtues. In turn, similarities in the conceptions of the virtues in apparently distant authors such as Aquinas and Al-Ghazali show a potential overlapping in their conception of practical reason. There are important examples such as the virtue of hope that is explicitly treated in both Aquinas and Al-Ghazali within their lists of theological/mystical virtues that lead the believer close to God and to otherworldly perfection. The three main theological virtues in Aquinas-faith, hope and charity - are paralleled by a much longer list in Al-Ghazali, including, among others, repentance, patience, gratitude, fear, poverty, ascetism, love, etc. ${ }^{59}$

The place of humility in Aquinas' account deserves our attention insofar as it is a well-known Christian virtue, though not a central one in his account. In the Thomistic philosophical ordering we find humility discussed at Question 161 as a sub-distinction of temperance, so in a secondary position that seems to diminish its importance. However, Aquinas is well aware of the position of humility in the Scripture and the Christian tradition before him. ${ }^{60}$ His treatment is surely influenced by Aristotle who takes it as a defect in considering one's own worth. The magnanimous person rightly thinks himself worthy of great things, while the temperate person thinks he is worthy of little and rightly

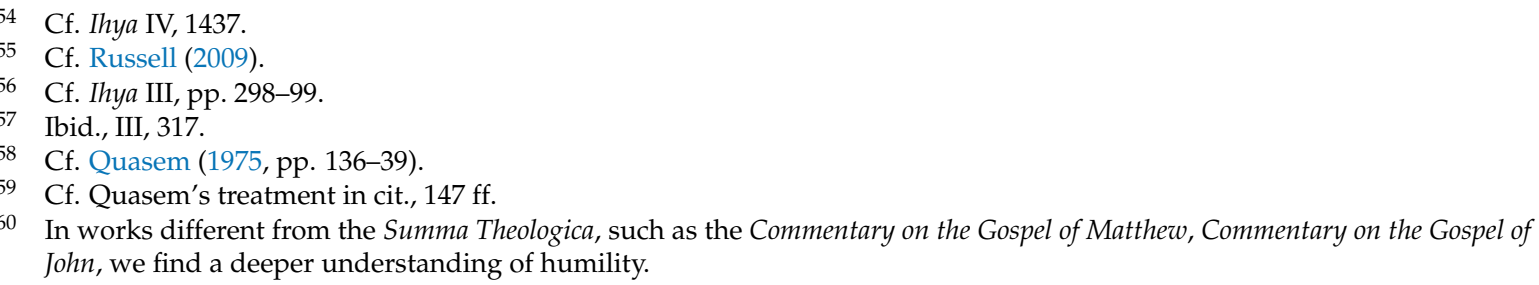


thinks so. ${ }^{61}$ From this point of view humility is the vice of he who does not recognize his own worth and does not expose to others his own qualities, even when he rightly possesses them.

In the Thomistic treatment of humility the religious element obviously makes a basic difference with regard to Aristotle. Humility is submission of man to God, awareness of one's finitude and limitedness against divine perfection. ${ }^{62}$ At the same time humility is also dependence on others and the virtuous does not want to locate himself above others: one has always to look for and prefer what is divine in our neighbors to what is human. In his constant effort to keep together Aristotelian and Christian ethics Aquinas admits the possibility of coexistence between humility and magnanimity. The latter is interpreted as the virtue which ushers men to great achievements according to the order of reason. Humility comes in limiting the desire for honors, the pride of he who is aware of his great achievements. Humility does not thwart excellent persons but makes them aware of their limits and defects. A larger outlook that includes the awareness of God makes this move possible.

The evident overlapping between Aquinas' and Al-Ghazali's account of the virtues-both moral and theological-leads to a common understanding of practical reason in which the good of individual excellence is not rejected but interpreted within a larger framework in which the divine marks and determines what counts for human beings. As already noticed at the start of these reflections, I would dub as (a version of) 'reasonableness' this conception of practical reason in which the search for the good life and excellence in human beings is tempered by the awareness of God and His perfection.

Finally, in order to give account of the main areas of Al Ghazali's ethics in which to detect reason at work we should consider the notion of maslaha. According to Emon's reconstruction of Soft Natural Law, Al-Ghazali uses the term maslaha to fuse fact and value in nature and, so, to grant ontological authority to reason within the Shari'a. As already shown, this position of reason leaves the way open to divine grace and to God's voluntaristic omnipotence. ${ }^{63}$ "God is not bound to do the good, but He does so out of His choice and purposiveness". 64 Practical and legal reasoning can be soundly based on maslaha because, according to Al-Ghazali, this entails the preservation of religion, life, intellect, lineage and property. ${ }^{65}$ These are the basic values of Shari'a and are intuitively known (the maqasid al-Shari'a).

There may be different kinds of maslaha and not all of them enjoy the authority deriving from a strong nexus to the Shari'a. Those which are especially interesting to our purposes are the 'silent maslaha', purposes of the law on which the scriptural sources are silent. In turn, silent maslaha are of a lower or higher order according to the kind of nexus they pose to Shari'a values. In an order of decreasing importance the nexus may be "a necessary interest, a basic need and an edificatory interest". These different degrees of importance entail different degrees of closeness to the well-being of society. New Shari'a rules can be created only out of necessary interests (darura), provided that the interests at stake can be certainly satisfied by the proposed course of conduct and that the interest must be for the benefit of society at large. Al Ghazali employs the well-known example of Muslims used as human shields by unbelievers waging war against Islam. The question is whether to strike, killing innocent Muslims, or refrain from striking, letting the unbelievers conquer the land of Islam. In the second case, he argues, the unbelievers will kill all the Muslims and the prisoners too. Thus, the conclusion of this practical reasoning is that the tighter nexus to the aim of the law is the first option. This is the maslaha to be applied for the general good of society, not for a utilitarian calculus in favor of the many. One final point to keep in mind is that Al-Ghazali's practical reasoning determines a maslaha by intuition that knows with certainty the law's purposes, needing no scriptural evidence. Intuition, however, does not operate from empty but from a contextual understanding of the details of the case. ${ }^{66}$

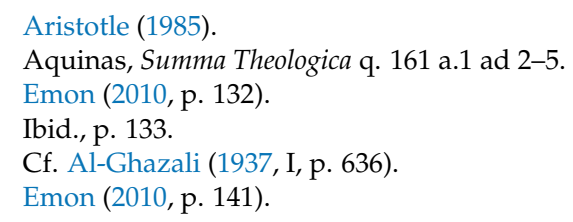


Once again we can see a parallel between Al-Ghazali's understanding of reason and the Aristotelian tradition (later developed by the Aquinas).

\section{Ibn Taymiyya's Consequentialist Reasoning}

The second author of the Islamic tradition I want to consider cannot be properly included in the Soft Natural Law trend of ideas as Al-Ghazali or Al-Razi-nor, however, in the Hard Natural Law movement. Ibn Taymiyya is often considered as an inspirer of some contemporary Islamist radical positions and, in this guise he would not have found a place in our discussion. However, some recent reconstructions have shed new light on the place of reason in his work. ${ }^{67}$ So, rather than speaking of a fundamentalist and intolerant theologian who opposed mysticism to reason, as he has been charged with, we have good arguments to consider him "the master of the via media, the middle way that is at the heart of traditional Islam". ${ }^{68}$ Given the huge amount and disorderly character of Ibn Taymiyya's work, it is difficult to proceed along lines parallel to those of writers who are more firmly within the rails of traditional Islamic ethics. Ibn Taymiyya is a theologian who looks at ethics from a perspective in which the relation between reason and revelation in epistemological terms is more outstanding than his treatment of specific issues such as the virtues. I shall limit my considerations to three points: (1) ethical epistemology, meaning our knowledge of right and wrong by reason and revelation; (2) Ibn Taymiyya's account of the foundations of value offered in terms of a teleological view; (3) finally, in terms more engaged with social and political practice, we shall consider his use of maslaha, similar to Al-Ghazali's. What emerges from the discussion, I want to emphasize by way of anticipation, is a general outlook on God and the human beings in which the first sets a stage that reason can reach and understand within the rails of revelation. Although Ibn Taymiyya does not propose any explicit and straigthforward view of ethics, his stress on human welfare as the aim of all God's actions and the place of reason in reaching for welfare brings him close to his predecessor Al-Ghazali and to Aquinas.

(1) The via media of Ibn Taymiyya does not consist in searching the truth in a middle ground between extremes but rather in a dialectical fashion of search which includes both poles. ${ }^{69}$ Ibn Taymiyya is open-minded as a theologian to the point of believing that the sound view "is the one that agrees with sound revelation and plain reason, which unites the elements of truth that different views contain and steers clear from the error they contain" ${ }^{70}$ This position seems to show harmony between reason and revelation. But can we say that this is true throughout all of Taymiyya's work? In other places, when he confronts the number of disputes and disagreements among persons of "mature reason", he seems led to think that reason exhibits a large degree of fractiousness and disorder. Evidence of this situation is offered in his view by the inexhaustible number of controversies, contradictions and disputes that animated the kalam (discursive theology) and philosophy of his time.

However, there is another basic concept in Ibn Taymiyya's ethics that comes to help and renew rationality: it is the idea of fitra, our "original nature". As Sophia Vasalou notices in opening her book, a recurrent theme among Muslim authors is that "Islam is the religion of our original nature". ${ }^{71}$ The point is that Islam, revelation through the Scripture, shows a relation of correspondence with the demands of our nature, our innate desires. Thus, the correspondence between reason and revelation seems to be replaced at several places by a relation of correspondence between revelation and fitra. At the epistemological level we can know right and wrong by the human fitra without contradiction with the content of the Scripture. (It is important to emphasize that we find in Ibn Taymiyya relations of correspondence between revelation, reason and human nature in a way very similar to the Aquinas'.)

\footnotetext{
Given the overwhelming amount of works by Ibn Taymiyya, it is outstanding the reconstruction by Vasalou (2012).

Michot (2012).

Cf. Swartz (1973, pp. 96-97).

Taymiyya (2009, p. 180).

Vasalou (2012, p. 1).
} 
The inclusion of fitra among the general epistemological criteria to achieve ethical knowledge also has consequences of the utmost importance at the substantial level of what counts as values for us. Emphasizing fitra (nature) we are led to move the focus of our attention from reason to desire, to what is desired in itself. Ibn Taymiyya expresses a hedonistic view according to which pleasure is the main spring of human action. "Every living being strives for what brings it enjoyment and pleasure" he writes in the Radd. Although most of Islamic ethics of his times was influenced by Aristotle, as with Al-Ghazali, Ibn Taymiyya differentiates his position along the lines of what we may call a 'welfarism' in which both the ideas of pleasure and utility play an important role. His welfarism is theologically based and developed in contrast with Asharite voluntarism. Against the latter and aligning himself with the Mutazilite Ibn Taymiyya held that acts have intrinsic qualities of good and bad, right and wrong. The Law sometimes just reflects these qualifications, other times is the source of new qualifications but it never expresses just an arbitrary divine power, disconnected from that benefit or welfare which is the aim of God's laws. ${ }^{72}$ The purposefulness of God's actions and their directions to human welfare leads Ibn Taymiyya to reject the Asharite claim of the inscrutability of God's will that remains dark to reasons. This refusal of crude voluntarism is one of the junctures of Ibn Taymiyya's thought that takes him close to Aquinas's understanding of the relationship between God and the world in which human beings live.

However, when we come to moral epistemology Ibn Taymiyya rejects Al-Ghazali's subjectivism which founds judgments of good and bad on individual (often egoistic) desires. On the grounds of fitra Ibn Taymiyya does not talk of what people 'call good and bad' but of what they know as good and bad, what is really good and bad and benefits or harms them. ${ }^{73}$ It is a position that gets to some extent in the direction of the Mutazilite's claim that acts possess intrinsic qualities of good and bad, escaping not only Al-Ghazali's subjectivism but also other Asharites' positions, such as Al-Shahrastani's alternative that leaves to the customs of a certain community the definition of good and bad actions. ${ }^{74}$

This substantial position combines with Taymiyya's foundational position expressed in teleological terms. Before commenting on this teleology, as opposed to the deontological approaches of his contemporaries, however, I should put forward one more consideration on the real thrust of reason within Ibn Taymiyya's thought. One can consider rationality as outside the domain of revelation, an independent standard, or as something that is already embedded within revelation. Jon Hoover writes that "revelation embodies true rationality"75 and Vasalou is close to the same lines of understanding when she says that reason "is alive inside the universe of God's speech". [ ... ] "Scripture teems with appeals to rational judgment and in many places clearly draws on rational considerations-what might be called arguments or, with the Quran, 'similitudes' (amthal)—-to produce conviction". ${ }^{76}$ Through many places of the Scriptures appeals to rational proofs seem to involve a substantial appeal to our rational capacities. However the appeal to rationality is more complex than what appears so far, as Vasalou recognizes. She subscribes Hoover's statement: "once one has access to revelation, one identifies it as identical to whatever truth one knew previously through reason". ${ }^{77}$ I believe we can spell out to some extent the position of reason vis-a-vis revelation. First, revelation constitutes what true rationality consists in. Here we find fitra at work with desiderative elements cooperating with cognitive elements that make up a connection with reason. In this picture a central place in discerning natural patterns and in making distinctions between likes and dislikes is taken by our

\footnotetext{
Taymiyya (1997a, 11: 354); cf. Vasalou (2012, pp. 141-42).

Cf. Vasalou (2012, pp. 109-10).

74 Cf. Al-Shahrastani (1934, p. 373). It is important to keep in mind that the positions in the two main fields-Asharites and Mutazilites-are complex and far from univocal. Al-Juwayni, for one, held that the normative force the Law has for us depends on the fact that prior to revelation we rationally exhibit evaluative responses to benefit and harm. The notion of obligation is underwritten by our capacity to experience punishment and pain. Cf. Al-Juwayni (1992).

75 Hoover (2007, p. 31).

76 Vasalou (2012, p. 235).

77 Hoover (2007, p. 31).
} 
capacity for analogy. ${ }^{78}$ Second, the harmonious integration between revelation and the natural and rational capacities of human beings is shown by a further point: the Shari'a particularizes and clarifies what the natural constitution knows in general. The law helps to discern what should be done and what should be avoided.

(2) As already mentioned, at the level of substantial evaluation Ibn Taymiyya uses concepts such as pleasure or welfare that locate him uncompromisingly in a utilitarian position. It is characteristically utilitarian in that the main object of human motivation is not personal utility or welfare but the welfare of the community. By contrast, the place of justice in Taymiyya's thought is controversial but a short quotation may be explicative also of the relation between utility and justice. The communal interest is the first type of value and justice may contribute to it: "the case in which an act contains benefit or harm ... the way it is known that justice serves the good of the world and injustice tends to its harm". ${ }^{79}$

Justice appears crucially in the Mutazilite ethical theory as a deontological notion with objective value, while Ibn Taymiyya gives pride of place to consequences and welfare. However, often his statements reflect contrasting premises in his understanding, as when he says that "the Law distinguishes between the acts that benefit [people] and the acts that harm them, and this is the justice of God in His creation" ${ }^{80}$ It is plausible to follow Sophia Vasalou's proposal to take the teleological framework of welfare as prior to considerations of justice which find their place in disciplining those commutative transactions by which people try to achieve their welfare. ${ }^{81}$ In a way also basic prohibitions, such as those against killing, adultery and theft, are means to attain basic goods (maqasid al-Shari'a) that contribute to the general welfare. Ultimately, all considerations of justice and injustice, as much as those regarding the virtues—-such as courage, chastity and honesty-reduce to utility, to what is beneficial or harmful to human welfare. In a Humean fashion Ibn Taymiyya characterizes all evaluative considerations in terms of one single value, utility or welfare. Even typically deontological acts such as those of justice and injustice are considered in terms of consequences and utility is regarded from the point of view of the social community rather than from an egoistic point of view. ${ }^{82}$

(3) We are now in a good position to make our last move that combines epistemological rationalism and ethical objectivism in a 'quasi-legal' procedure that follows Al-Ghazali scheme. From what follows it seems that Ibn Taymiyya wants to enlarge the boundaries of a legislation aimed at welfare. From Al-Ghazali's distinction we can recall a three-tiered scheme organizing the interests promoted by the Law in "necessary interests, basic needs and edificatory interests". We already know that the more urgent category which legislators should pursue and eventually enlarge beyond the scriptural sources is that of 'necessary interests'. We also know the conceptual tool of the 'silent maslaha' as a crucial means to pursue the welfare of the community as a whole. Ibn Taymiyya wants to go beyond the five explicit interests of the Shari'a: religion, intellect, life, property and lineage. He takes this list as articulated mainly with a focus on punishments to deflect harm from positive goods. By contrast, Taymiyya wants to focus on those worldly "transactions and acts which are said to serve the welfare of people in the absence of a legal prohibition". ${ }^{83}$ This general reference to transactions and acts goes much beyond the scheme of the silent maslaha and serves a broad goal of human welfare, encompassing all that is beneficial to society. This point may lead us to think that Ibn Taymiyya endorses a sweeping ethical rationalism that applies in all cases to increase the overall utility of actions. By contrast, Vasalou emphasizes that Taymiyya's statements are more complex and make room for another reading in

78 Vasalou (2012, pp. 236-37). The use of analogy (qiyas) within the framework of Muslim consensus as a way to communicate the truth of revelation is held also by Makari (1983).

79 Taymiyya (1997b, 8: 434-35).

80 Taymiyya (1997c, 29: 188).

81 Vasalou (2012, pp. 50-52).

82 Following Vasalou, it is worth-noticing that Ibn Taymiyya is on the same side with Hume in denying that morality is in conformity with reason and driving a wedge between the divine and the human where the latter can trust our feelings of 'approbation and disapprobation' to identify what has value. Cf. ibid., pp. 133-34.

83 Taymiyya (1997a, 11: 342-43). 
which "the confrontation with utility he has in mind is not as substantive as appears but should rather be understood as taking place on interpretive terms within the regulating framework of Scripture". ${ }^{84}$ Such a position seems to drive out entirely silent maslaha as means to engage considerations of welfare when the Law does not have expressive prescriptions. Ibn Taymiyya's way out is through the notion of human need. "Human need is not only the basis for exceptionally suspending or relaxing the demands of the law; it is also the basis for permitting action that the Law has not expressly prohibited, telling us how to act in the face of the Law's silence" ${ }^{85}$ When he comes to the permissibility of contractual terms Ibn Taymiyya says that a set of legal terms should not be prohibited-unless it contravenes a legal prohibition or is self-defeating-because it is an act that people desire and need..$^{86}$

In the end, if we want to sketch as clearly as possible the fragmentary and sometimes contradictory observations that Ibn Taymiyya makes on the role of reason vis-a-vis revelation and, thus, in our attempt to catch the interpretation of maslaha, we should consider two points. First, reason and our natural resources (e.g., fitra) may lead us in the right direction, showing what is in our interests in general. But it is the prophetic message, revelation, that allows us to know "the details of what is beneficial and harmful in this life and the next" ${ }^{87}$ Second, we should make clear that reason, according to Ibn Taymiyya does not have a decisive role in closing disputes. He does not side with rationalist-minded factions, though he preserves for reason an important role. It is both outside revelation insofar as it convinces us of foundational facts about God and it is inside in so far as the Scripture appeals in many places to our rational judgment and uses arguments to produce convictions. ${ }^{88}$ In other words, a silent maslaha can be a legitimate prescription only when scriptural underpinnings can be traced behind rational arguments.

\section{Conclusions}

The proposed goal of this short discussion was that of tracing a common area of values to which both Western (secular and Christian) and Islamic citizens would be willing to give their consent without giving up too many constitutive features of their culture. It might be objected that an attempt of this sort has been made already, using the conceptual framework of Rawls "public reason". ${ }^{89}$ The general framework provided by the idea of public reason is surely a helpful contribution to the discussion of all those citizens who are willing to follow Rawls's scheme of public reason. One of his

\footnotetext{
Vasalou (2012, p. 209).

Ibid., p. 211.

Cf. Taymiyya (2001, p. 281).

Cf. Taymiyya (1997d, 19: 100).

Cf. Vasalou (2012, p. 235).

9 Fadel (2007) Another important attempt at filling the gap between Islamic cultural values and liberal citizenship and values - what Rawls synthetizes in the expression 'constitutional essentials' - comes from March (2009). He declares to be in search of a minimal account of the demands of liberal citizenship that be least in conflict with the demands of Islamic political ethics. The goal of overlapping consensus is important especially to provide social stability for comprehensive doctrines which adhere to the scheme of political reasonableness, endorsing liberal moral principles. He recognizes that the precise contours of certain social policies or principles may depend on the dialectical engagement between a conception of justice and the conceptions of the good which are in dialogue with it. What he, as most political liberals, refuses to tackle is the possibility that there is a conception of the good underlying liberalism stronger than what Rawls's followers believe. Such a conception that might be sketched along the lines of some liberal perfectionist idea might define the contours of what a liberal state may or may not accept from comprehensive doctrines such as Islam. I have started to sketch some view of this kind in my "Excellence Despite Disagreement. A Reasonable Conception?", forthcoming in Rivista Internazionale di Filosofia del Diritto (Mangini, forthcoming).

Abdullahi Ahmed An-Na'im argues toward a goal similar to March's but along different lines. In Islam and the Secular State he affirms uncompromisingly that there are liberal constitutional values, such as freedom of religion and human rights in general which require to Muslims a reinterpretation of the Shari'a. This move should not induce the reader to think that his view gives hierarchical priority to "civic reason"- something very close to Rawls's 'public reason'—over Islam because he makes the bold claim that if he had to choose at some point between Islam and human rights, he would certainly opt for the first (Ibid., 111). His way out of the impasse is that of proposing the Madisonian strategy of the Federalist Paper no. 10: reducing Shari'a to one of the many interest groups in civil society the state can deal with normative politics on the one side and, on the other, with a religious part of citizenry that cannot leave religion as a source of political inspiration. Cf. Fadel (2009-10).
} 
basic presuppositions is that citizens hold "incompatible conceptions of the good" and that public reason may offer a scheme of "constitutional essentials" to which they can lend their consent, while keeping their "comprehensive conceptions" in their private lives. My attempt here starts from the optimistic assumption that we can find less incompatibility among conceptions of the good than what Rawls thought. If we consider the present level of conflictuality among citizens who belong to the same cultural framework - e.g., Westerners who give their allegiance to Rawls's constitutional essentials-it would seem extremely implausible to assume more compatibility among Westerners and Islamic citizens. In order to avoid the charge of over-ambitiousness and implausibility I believe we should not focus on the level of substantial conceptions of the good-where differences and disagreements are legion-but at the meta-ethical level at which we discuss concepts such as reason and desires.

I claim that between Western and Islamic ethics there is room for a conception of reason-we might call it "reasonableness" - that relies on an ancient and sound philosophical tradition. It is an idea basically connected to human flourishing and, so, it stands in a dialogical relation with desires and will and cooperates with the virtues as its operative branch. This understanding of reasonableness is what we can find originally in Aristotle's ethics and is, then, developed by Aquinas and Al-Ghazali. Ibn Taymiyya is less aligned but an inquiry into his position may still be useful to grasp a certain view of reason that does not run too far away from the former. In turn, this renovated conception of reason makes room for a variety of conceptions of the good which present a large degree of mutual compatibility.

In order for this view to acquire consent we need to tackle two influential competitors whose views of reason undermine the plausibility of the conception of 'reasonableness' that we are trying to develop here: Kant's and Hume's views. They are commonly considered views competing with each other and presenting incompatible understandings of reason and ethics. As we know, Kantian and Humean theorists continue the discussion in our times, being persuaded that no other worth-considering proposal can be put forward in contemporary ethics. Either (practical) reason, according to Kant, is divorced from the agent's emotions and desires and rationality dictates universalizing norms or reason is only "the slave of passions", according to Hume, and has no independent (practical) role in disciplining feelings and desires. As we already know, moral judgments depend on feelings of pleasure and displeasure, with no contribution from practical reasoning. In both cases the two philosophers use a subjectivist conception of happiness interpreted as the maximization of desire(or preference-) satisfaction.

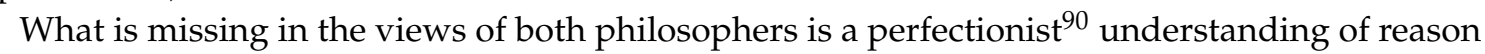
as working in cooperation with human flourishing. Practical reasoning includes the ends of human conduct and can discipline desires to some extent, while accepting the value of emotions. What follows can be taken as the gist of the classical tradition that can be traced from Aristotle to Aquinas-and beyond. The main points that should be kept in mind in summarizing the classical Western view can be helpful in finding overlapping with Islamic views. In short, there are fundamental inclinations that lead human beings to pursue some goods which are commonly necessary to human life. The pursuit of these goods structures a conception of well-being in which desires are well ordered through a rational integration and activate the virtues which are, then, applied to action in different spheres of conduct. Virtues in operation account for the perfection of the agent through the working and coordination of prudence or practical wisdom. I would call this operation of practical wisdom 'reasonableness' in the sense already explained. It closes the distance between ideals of a happy life and particular situations of application. In an inclusive form it also encompasses the "will" as the psychological element that focuses on interiority and shapes reasons according to the agent's particularity. It is crucial to keep in

90 Liberal perfectionism is by now a growing theoretical corpus which presents different views but in general, on the one hand, we can say that consists of a common rejection of the principle of neutrality, that characterizes Rawlsian mainstream political liberalism, and, on the other, proposes a view of the state as promoting some ideal of human development grounded in human nature. Among most recent works in the liberal perfectionist camp see Kramer (2017). 
mind that this is an "ethical" conception of reasonableness that remains well distinct from Rawls's political understanding of "public reason". In principle, however, nothing prevents a certain degree of integration between the two views.

In the Islamic camp we find an understanding of reason and a relation to ethics that resembles to a large extent the classical tradition. This is true not only for the rationalist view dubbed as "hard natural law" but also for the alternative "soft natural law" view. Both views allow for some degree of objectivism of value but the latter sets a limit to the power of reason to define the good and the bad by subjecting it to God's grace. The "fusion of fact and value" that underlies soft natural law views can be traced also in the work of the great Islamic thinker Al-Ghazali. Notwithstanding his mystical inclinations, he believes that reason and revelation are complementary in pursuing otherworldly happiness and perfection. He stresses action in this world and habituation to harness the passions of the soul through the virtues that operate within the context of the good character. Further, also in Al-Ghazali, as in the classical tradition, we find the centrality of wisdom. The place of reason is strengthened by the use of the notion of maslaha in which fact and value are fused and connected to the Shari'a through the maqasid. Having emphasized the resemblances, it is only fair to recall that Al-Ghazali also holds an extended doctrine of "mystical virtues" which takes him some steps away from the classical tradition, though not so much from Aquinas' theological virtues.

Finally, we can grasp from recent reconstructions that also Ibn Taymiyya, a thinker usually considered a fundamentalist theologian, can be reconceived in terms of a via media between reason and revelation in which an important place is also kept for our "natural constitution" (fitra), an idea that is close to Aquinas "fundamental human inclinations". Reason and revelation are integrated in Taymiyya's view to the point that the fractiousness and disorder of the former can find definitive solution only in the words of the latter. But the Scripture, in turn, often makes appeal to rational arguments: revelation does not run against rationality but constitutes what true rationality consists in. In so far as also fitra works with desiderative elements in cooperation with cognitive elements, the degree of similarity between Ibn Taymiyya's picture and Aquinas' seems evident.

However, these resemblances should be carefully considered because at a more substantial level we find Ibn Taymiyya's teleological understanding in terms of consequences and welfare. His view here seems to belong clearly to the utilitarian camp, setting aside perfectionist considerations. But the appeal to utility or welfare is more complicated than how it appears on a first view. First, all confrontations with utility take place within the regulating framework of the Scripture and even in the case of a silent maslaha or "human needs" reason cannot define an independent conclusion but is always brought back to scriptural underpinnings. Taymiyya tries to balance carefully scriptural constraints with the claims of reason that emerge more urgently from silent maslaha and human needs. Second, he does not trust human desires as they are but relies on fitra and on knowing what is good and bad for human welfare. Here I take a view of 'ethical reasonableness' to surface again, as in Aquinas' view, although with a less explicit perfectionist thrust.

In conclusion, can we say to have traced a univocal conception of reasonableness from the works of Aquinas, Al-Ghazali and Ibn Taymiyya (keeping Aristotle on the background)? Or, should we say that the differences overcome the resemblances, leaving not enough room for a univocal view? I believe we can keep an optimistic understanding of 'ethical reasonableness' as a mode of reasoning connected to human nature and aimed at human happiness or perfection more clearly in the case of Aquinas and Al-Ghazali than in the case of Ibn Taymiyya, although many signs in the latter let us conjecture that his views on human welfare, reason and revelation bring him much closer to the classical view than to the ethical subjectivism of modern moral theories.

Funding: This research received no external funding.

Conflicts of Interest: The author declares no conflict of interest. 


\section{References}

Al-Ghazali. 1898. Ihya' ‘Ulum ad-Din. 4 vols. Cairo: Al-Matba'a al-Azhariya.

Al-Ghazali. 1937. al-Mustasfá fi 'Ilm al-Usul. Cairo: Al-Maktaba at-Tijariya.

Al-Ghazali. 1961. Faisal at-Tafriqa bain al-Islam wa-z-Zandaqa. Cairo: Dar Ihya' al-Kutub al-'Arabiya.

Al-Ghazali. 1963. Mizan al-'Amal. Cairo: Maktabat Sabi.

Al-Juwayni. 1992. Al-'Aqūda al-Nizāmiyya fi'l-arkān al-Islāmiyya. Edited by Muhammad Zāhidal-Kawtharī. Cairo: al-Maktaba al-Azhariyya, pp. 58-59.

Al-Shahrastani. 1934. Nihāyat al-iqdām fì 'ilm al-kalām. Edited by Alfred Guillaume. London: Oxford University Press. Aristotle. 1985. Nicomachean Ethics. Translated by T. Irwin. Indianapolis: Hackett, vol. 1123b, pp. 2-8.

Emon, A. 2010. Islamic Natural Law Theories. Oxford: Oxford University Press.

Fadel, M. 2007. The True, the Good and the Reasonable: The Theological and Ethical Roots of Public Reason in Islamic Law. University of Toronto Legal Studies Series; Res. Paper n. 977206. Toronto: University of Toronto.

Fadel, M. 2009-10. "Islamic Politics and Secular Politics: Can They Co-Exist?”, review of Abdullahi Ahmed An-Na'im. Islam and the Secular State, Journal of Law and Religion 25.

Fakhry, M. 1991. Ethical Theories in Islam. Leiden: Brill.

Finnis, J. 1998. Aquinas. Oxford: Oxford University Press.

Griffel, F. 2009. Al-Ghazali's Philosophical Theology. Oxford: Oxford University Press.

Hoover, J. 2007. Ibn Taymiyya's Theodicy of Perpetual Optimism. Leiden: Brill.

Hume, D. 1888. Treatise on Human Nature. Edited by L.A. Selby-Bigge. Oxford: Clarendon Press, p. 320.

Kant, I. 1964. Groundworks for the Metaphysics of Morals. Translated by H.J. Paton. New York: Harper, vol. 4, (Numbers of pages refer to the complete edition of Kant's works: Kant's Gesammelte Schriften, von der Königlich-Preußische Akademie der Wissenschaften zu Berlin, Berlin 1902 ff.).

Kant, I. 1991. The Metaphysics of Morals. Translated by M. Gregor. Cambridge: Cambridge University Press.

Kant, I. 2015. Critique of Practical Reason. Translated by M. Gregor. Cambridge: Cambridge University Press.

Kramer, M. 2017. Liberalism with Excellence. Cambridge: Cambridge University Press.

Makari, V. 1983. Ibn Taymiyya's Ethics. The Social Factor. Chico: Scholars Press.

Mangini, M. Forthcoming. Excellence Despite Disagreement. A Reasonable Conception? Rivista Internazionale di Filosofia del Diritto.

March, A. 2009. Islam and Liberal Citizenship: The Search for an Overlapping Consensus. Oxford: Oxford University Press. Michot, Y. 2012. Against Extremisms. Paris: Albouraq Editions.

Nussbaum, M. 2000. Women and Development: The Capabilities Approach. Cambridge: Cambridge University Press. Porter, J. 2005. Nature as Reason. Grand Rapids: Eerdmans.

Quasem, M. A. 1975. The Ethics of Al-Ghazali. Petaling Jaya: Quasem.

Russell, D. 2009. Practical Intelligence and the Virtues. Oxford: Oxford University Press.

Sen, A. 1999. Development and Freedom. New York: Random House.

Setiya, K. 2004. Hume on Practical Reasoning. Philosophical Perspectives 18: 365-89. [CrossRef]

Swartz, M. 1973. A Seventh Century (A.H.) Sunni Creed: The Aqida Nasitiya of Ibn Taymiyya. Humaniora Islamica 1.

Taylor, C. 1982. The Diversity of Goods. In Utilitarianism and Beyond. Edited by B. Williams and A. Sen. Cambridge: Cambridge University Press, pp. 129-44.

Taylor, J. 2002. Hume on the Standard of Virtue. The Journal of Ethics 6: 43-62. [CrossRef]

Taymiyya, Ibn. 1997a. Qā'ida fi'l-mu'jizāt wa'l-karāmāt. In Majmū'Fatāwāa. Reprint of Original 1381-86/1961-67 Riyad Edition. Beirut: Mu'assasat al-RisRla.

Taymiyya, Ibn. 1997b. Mas'alat tahsin al-aql wa-taqbihuhn. In Majmū̄'Fatāwāa. Reprint of Original 1381-86/1961-67 Riyad Edition. Beirut: Mu'assasat al-RisRla.

Taymiyya, Ibn. 1997c. Qa'ida fina yajibs min al-mu'awadat wa-nahwa dhalika. In Majmū'Fatāwā. Reprint of Original 1381-86/1961-67 Riyad Edition. Beirut: Mu'assasat al-RisRla, vol. 29, p. 188.

Taymiyya, Ibn. 1997d. Qa'ida nafi a fi wejub al-i'tisam bi'l-risala. In Majmū'Fatāwā. Reprint of Original 1381-86/1961-67 Riyad Edition. Beirut: Mu'assasat al-RisRla.

Taymiyya, Ibn. 2001. Al-Qawā id al-nūrāniyya al-fiqhiyya. Edited by Aḥmad ibn Muhammad al-Khalīl. Dammam: Dār Ibn al-Jawzī.

Taymiyya, Ibn. 2009. Sharḥ al-Iṣbahāniyya. Edited by Muḥammad bin 'Awda al-Sa 'awī. Riyad: Dār al-Minhāj. 
Aquinas, Thomas. 1888-1906. Summa Theologica. In Opera Omnia iussa edita Leonis XIII P.M.. Rome: ex Typographia Poliglotta S.C. de Propaganda Fide, (Abbreviated in S.T. in the text).

Vasalou, S. 2012. Ibn Taymiyya's Theological Ethics. Oxford: OUP.

Williams, B. 1980. Internal and External Reasons. In Moral Luck. Cambridge: Cambridge University Press.

Wood, A. 2013. Kant on Practical Reason. In Kant and Practical Justification: Interpretive Essays. Edited by M. Tummons and S. Baiasu. Oxford: Oxford University Press. 